\title{
The goal of blood pressure in the hypertensive patient with diabetes is defined: now the challenge is go from recommendations to practice
}

\author{
Patricio Lopez-Jaramillo ${ }^{1,2^{*}}$, Jose Lopez-Lopez ${ }^{3}$, Cristina Lopez-Lopez ${ }^{3}$ and Miguel I Rodriguez-Alvarez ${ }^{3}$
}

\begin{abstract}
The recent Latin American and European guidelines published this year has proposed as a goal for blood pressure control in patients with diabetes type 2 a value similar or inferior to 140/90 $\mathrm{mmHg}$. High blood pressure is the leading cause of cardiovascular diseases and deaths globally. Although once hypertension is detected, $80 \%$ of individuals are on a pharmacologic therapy only a minority is controlled. Diabetes also is a risk factor for other serious chronic diseases, including cardiovascular disease. Whether specifically targeting lower fasting glucose levels can reduce cardiovascular outcomes remains unknown. Hypertension is present in $20 \%$ to $60 \%$ of patients with type 2 diabetes, depending on age, ethnicity, obesity, and the presence of micro or macro albuminuria. High blood pressure substantially increases the risk of both macro and micro vascular complications, doubling the risk of all-cause mortality and stroke, tripling the risk of coronary heart disease and significantly hastening the progression of diabetic nephropathy, retinopathy, and neuropathy. Thus, blood pressure lowering is a major priority in preventing cardiovascular and renal events in patients with diabetes and hypertension. During many years the BP goals recommended in patients with diabetes were more aggressive than in patients without diabetes. As reviewed in this article many clinical trials have demonstrated not only the lack of benefits of lowering the BP below 130/80 mmHg, but also the J-shaped relationship in DM patients. Overall we discuss the importance of define the group of patients in whom significant BP reduction could be particularly dangerous and, on the other hand, those with a high risk of stroke who could benefit most from an intensive hypotensive therapy. In any case, the big challenge now is avoid the therapeutic inertia (leaving diabetic patients with BP values of $140 / 90 \mathrm{mmHg}$ or higher) at all costs, as this would lead to an unacceptable toll in terms of human lives, suffering, and socioeconomic costs.
\end{abstract}

Keywords: Hypertension, Diabetes, Guidelines, Blood pressure

\section{Introduction}

The recent Latin American [1] and European [2] guidelines published this year has proposed as a goal for the blood pressure control in patients with diabetes type 2 a value similar or inferior to $140 / 90 \mathrm{mmHg}$. The American Diabetes Association (ADA) [3] guidelines recommended similar value for systolic blood pressures but for diastolic blood pressure the recommended value was lower that $80 \mathrm{mmmHg}$.

\footnotetext{
* Correspondence: jplopezj@gmail.com

${ }^{1}$ Research Institute and Clinic of Diabetes and Metabolic Syndrome, Fundación Oftalmológica de Santander (FOSCAL), Calle 155 A No 23-09, Torre Milton Salazar, Urbanizacion El Bosque, Floridablanca, Santander, Colombia ${ }^{2}$ MASIRA Research Institute, Medical School, Universidad de Santander (UDES), Bucaramanga, Colombia

Full list of author information is available at the end of the article
}

The important role that increased levels of blood pressure have as one of the principal risk factors to myocardial infarction (MI) [4] and stroke [5], made this mater one of special interest that need be very well supported and universally accepted in perspective of improve the lowers levels of hypertensive control reported worldwide. Recently, the Prospective Urban Rural Epidemiology (PURE) study demonstrated the high prevalence of hypertension and the very low awareness, treatment and control of hypertension worldwide [6]. This community based study included 153,996 adults (35-70 years) from 628 rural and urban communities from three high- income countries (HICs), 10 upper middle and low middle income (UMIC and LMIC) and four low-income countries (LIC) in various parts of the world. Hypertension was defined when 
individuals reported treatment for hypertension or had an average blood pressure (BP) greater than 140/90 $\mathrm{mmHg}$ from two measures of resting sitting BP using an automated digital device. Overall, $40.7 \%$ of participants were found to have hypertension, with $13.3 \%$ having a BP of at least $160 / 100 \mathrm{mmHg}$ and $4.4 \%$ a BP of at least $180 / 110 \mathrm{mmHg}$. Of those with hypertension, $46.4 \%$ were aware of this condition, $40.6 \%$ were on pharmacological treatment, but only $13.1 \%$ had BP controlled $(<140 / 90 \mathrm{mmHg})$. Overall, $12.5 \%$ of treated hypertensive patients received two or more BP lowering medications, with a decreasing trend from wealthier to poorer countries (HIC, 18.1\%, UMIC 14.5\%, LMIC 14.1\%, LIC 1.6\%; P < $0.0001)$. Hypertension prevalence was highest in participants with diabetes (63\%), and even though awareness was $74.4 \%$, and the percentage of those who received treatment $69.3 \%$, the control rate was only $23.3 \%$. So, it is crucial to improve the control of blood pressure in a group of high risk, as is the diabetic population.

In the present article we review the crucial role of hypertension and diabetes in the risk of develop cardiovascular diseases (CVD) and the evidences that support the decision of the Latin Americans and Europeans experts, with the aim of motivating to the health team and the subjects affected of hypertension and diabetes to participate actively in the challenge to pass from the guidelines recommendations to the clinical practice and public health programs to improve the percentage of control of blood pressure.

\section{The role of hypertension in the global burden of cardiovascular disease}

Cardiovascular diseases are the major causes of mortality and morbidity globally and affect over $50 \%$ of men and $40 \%$ of women over their lifetimes $[7,8]$. Although age adjusted mortality for CVD is decreasing in developed countries, there is a sharp rise in developing countries $[9,10]$. In 1990, 5.3 million CVD deaths occurred in developed countries, whereas there were about 9 million deaths from CVD in developing countries [11]. In addition, CVD in developing countries occurs at a younger age. In the same year (1990) the proportion of deaths due to CVD in those $<70$ years in developed countries was $26.5 \%$ of total deaths, while in developing countries it was $46.7 \%$. It was estimated that the disability adjusted life years (DALY's) lost in developing countries was about three times greater than that in the developed countries [12]. Consequently, approximately three quarters of the global mortality and perhaps about $80 \%$ of the disease burden (measured as DALY's lost) is expected to occur in low and middle income countries ( $\mathrm{L}+\mathrm{MIC})$ by the year 2020 [13]. These numbers have not materially changed in the last years; Thus, in 2011 two of 3 deaths each year are attributable to non-communicable diseases (mainly heart disease, stroke, diabetes, cancers and chronic respiratory disease) with four fifths of the deaths occurring in $\mathrm{L}+\mathrm{MIC}$, with a third occurring in people younger than 60 years. Overall, age specific non- communicable disease deaths are two times higher in $\mathrm{L}+\mathrm{MIC}$ than in high-income countries [14-16].

High blood pressure BP is the leading cause of CVD and deaths globally. It is associated with 7.5 million deaths (which represents one-eighth of all deaths) per year worldwide $[7,8]$. The importance of BP as a modifiable risk factor for CVD is well recognized and many effective and inexpensive BP-lowering treatments are commonly available $[17,18]$. Therefore, BP control and prevention of related morbidity and mortality could be clearly achievable. However, the awareness, treatment and control of hypertension are low in all countries, despite hypertension being an easily detectable, common and well established risk factor for CVD. The reasons for a persisting huge gap in awareness and treatment of hypertension, despite the identification and control of blood pressure being prioritized by many national and global organizations and despite the availability of cheap and effective medications are unclear. Use of combination therapies, which is needed to control hypertension, is relatively uncommon even in wealthier countries. Although once hypertension is detected, $80 \%$ of individuals are on a pharmacologic therapy only a minority is controlled [6]. This suggests the need for a more aggressive approach to $\mathrm{BP}$ control (e.g. by using combination therapies). A recent study [19] using a meticulously algorithm applied to DM2 patients was able to lower BP, however more than half of the patients did not achieve the ADA/Joint National Committee on Prevention, Detection, Evaluation, and Treatment of High Blood Pressure: The Seventh Report (JNC 7) targets demonstrating the complexity of $\mathrm{BP}$ control in this population.

The BP Lowering Treatment Trialists Collaboration (BPLTTC) meta-analysis of individual patient data from over 160,000 participants in 29 trials showed that lowering systolic BP by $5 \mathrm{mmHg}$ over 4 to 5 years with most drugs, including blockers of the renin-angiotensin- aldosterone system (RAAS) reduced the risk of ischemic heart disease (IHD) by $20 \%$, stroke by $28 \%$ and major CVD events by $22 \%$, with additional reductions in heart failure [18]. Since five treatment groups (diuretics, beta blockers, angiotensin converting enzyme inhibitors, angiotensin receptors blockers and calcium channel blockers) have demonstrated not only anti-hypertensive but also cardio-preventive efficacy, as well as renal and cerebrovascular protection, all of them are of choice in patients with hypertension and diabetes type 2 (DM2). However, when selecting to start treatment with monotherapy, drugs that blocking the renin-angiotensin-aldosterone system should be primarily prescribed for its nefro-protective effect. 
Angiotensin receptors blockers (ARBs) are better tolerated, and this is very important issue in patients with chronic diseases such as hypertension and DM2 where adherence is essential. As a general rule, a long acting drugs providing protection for 24 hours must be indicated in order to use single doses, which offer greater protection and improve patient adherence to treatment [20,21]. Recently, a systematic review and bayesian network metaanalysis comparing the effectiveness of renin-angiotensin system blockers and other antihypertensive drugs in patients with diabetes, have concluded that the reno-protective effects and superiority of using ACE inhibitors in patients with DM2, and also that the available evidence is not able to show a better effect for ARBs compared with angiotensin converting enzyme inhibitors (ACEI). Calcium channel blockers might be the preferred treatment in combination with ACEI if adequate blood pressure control cannot be achieved by ACEI alone [22].

\section{Diabetes and cardiovascular diseases}

Diabetes is a metabolic disorder that is diagnosed when the fasting and/or post load glucose level rises above well-established thresholds. For instance, the criteria for diagnosis of DM2 adopted and recommended by the Latin American Consensus [1], are listed as follows:

1. Fasting glucose at least $126 \mathrm{mg} / \mathrm{dl}$ in two successive readings

2. At least $200 \mathrm{mg} / \mathrm{dl} 120 \mathrm{~min}$ after oral glucose tolerance test

3. At least $200 \mathrm{mg} / \mathrm{dl}$ at any time in the presence of symptoms

These thresholds were chosen because they identified people at particularly high risk for retinopathy based on epidemiological data. These data also have shown that people with diabetes and poorly controlled glucose levels have higher risks of retinopathy than people with diabetes and well-controlled glucose levels [23,24]. Diabetes also is a risk factor for other serious chronic diseases, including cardiovascular disease. Indeed, a recent metaanalysis of large prospective studies comprising 450.000 people showed that men and women with diabetes are 2 and 3 times more likely, respectively, to die of coronary heart disease than men and women without diabetes [25]. Moreover, epidemiological analyses of prospective data from the United Kingdom Prospective Diabetes Study (UKPDS), which recruited people with newly diagnosed diabetes showed that progressively higher HbA1c levels predicted higher hazards of severe retinal or renal disease, cataracts, myocardial infarction, heart failure, amputation or peripheral vascular disease, stroke, and death [26]. They also showed that the risk relationship differed with respect to outcome, with a stronger relationship to some outcomes and a weaker relationship to others. Thus, organ systems may vary in their susceptibility to damage related to glucometabolic abnormalities, a proposal strongly supported by epidemiological analysis [27].

Whether specifically targeting lower fasting glucose levels can reduce cardiovascular outcomes remains unknown. Some clues may reside in the 10-year-long UKPDS, which randomized people with newly diagnosed diabetes and few other cardiovascular risk factors to a policy of targeting fasting plasma glucose $108 \mathrm{mg} / \mathrm{dl}$ versus a conventional policy targeting fasting plasma glucose $270 \mathrm{mg} / \mathrm{dl}$ $[28,29]$. This study reported a clear reduction in myocardial infarction and death in a subset with recently diagnosis of DM2 and obese participants allocated to metformin as the means of glucose lowering, with no significant cardiovascular effects in the other participants [29]. Moreover, after 9 years of passive follow-up, all participants experienced a $13 \%$ and $15 \%$ reduction in death and myocardial infarction, respectively, and the subset given metformin retained the benefit observed during the active treatment phase [30]. These results have support the proposal that the intensive therapy to normalize blood glucose in perspective of prevent CVD is effective only if is started from the very begging diagnosed of DM2 [31].

Individuals with DM2 are less likely to survive a first myocardial infarction than their no diabetic peers. Therefore, early identification of coronary artery disease (CAD) in the diabetic population is needed. The mechanism of acute coronary syndrome and their implications for therapy haven recently reviewed [32], included the role of hyperglycemia [33]. However, the fact that CAD is often asymptomatic in diabetic patients makes such identification a challenge. A number of studies have shown that silent myocardial ischemia as evidenced by non-invasive tests such as the electrocardiogram stress test, myocardial scintigraphy or stress echocardiography affects $20-50 \%$ of diabetic patients with additional risk factors [34,35]. The term of silent ischemia includes an entity named true silent myocardial ischemia or clandestine ischemia, which is characterized by myocardial perfusion defects in the absence of both angina and ST-segment depression $>1 \mathrm{~mm}$ during the exercise test. In the largest study performed to evaluate the prevalence of silent myocardial ischemia in diabetic patients, the DIAD (Detection of Ischaemia in Asymptomatic Diabetics) study [34] reported that patients with DM2 have a high prevalence of silent myocardial ischemia and true silent myocardial ischemia. The detection of asymptomatic CAD was associated with a higher number of interventions, but without a benefit in outcomes. Recently [35] it was evaluate the prevalence of true silent myocardial ischemia in asymptomatic DM2 patients in comparison with a non-diabetic control group. Risk factors of CVD were similar between both groups. The prevalence of true silent myocardial ischemia was strikingly higher in DM2 than in their no 
diabetic peers (21.9\% vs. $2.4 \%)$. As previously reported in silent myocardial ischemia, men are more likely to have perfusion defects. Moreover, as occurs in silent ischemia the number of traditional risk factors is not useful as a means of identifying patients with true silent myocardial ischemia [36]. An important finding was that diabetes retinopathy (DR) is independently associated with the presence of true silent myocardial ischemia. DR has been recently recognized as an indicator of risk for CAD in diabetic patients [36] and it is predictive of cardiovascular mortality [37]. A recent meta-analysis that have included 20 studies and 19,234 subjects have shown that DR predicts all-cause mortality and CV events in both type 1 and 2 diabetic patients [38]. These results support the concept that micro and macrovascular complications of diabetes share common pathogenic mechanisms beyond those related to the classical risk factors. The common pathogenic mechanisms between micro and macrovascular complications are uncertain but there is emerging evidence to suggest that endothelial dysfunction, platelet dysfunction, oxidative stress, inflammation, and advanced glycation end products are pathogenic factors for both micro and macrovascular complications in diabetic patients [39]. Although costeffectiveness studies are still needed it is undeniable that DM2 could benefit from the identification of silent myocardial ischemia. In the DIAD study asymptomatic diabetic patients with moderate or large myocardial perfusion defects had a 6-fold greater cardiac risk than those with normal studies or small defects [34]. However, the meaning of a positive SPECT in the setting of true silent myocardial ischemia, in particular when perfusion deficits are of mild intensity, remains to be elucidated. Meanwhile, in terms of clinical practice it would be reasonable to be especially rigorous in achieving a tight control of risk factors and blood glucose in these patients. In the DIAD study, a more intensive treatment of cardiovascular risk factors was associated with the resolution of perfusion deficits [40]. In the study of Hernandez et al. [35], the probability of having myocardial perfusion defects in an asymptomatic diabetic patient with DR was 11.7 (IC95\%: 3.7-37). Therefore, patients with DR are good target population for indicating SPECT. This information is important not only for the management of diabetic patients but also in terms of the economic burden. The current guidelines already identify the need for routine screening for DR. In addition to appropriate vision care, the detection of DR might now also warrant a fuller cardiac evaluation and closer follow-up to prevent the development of CAD.

\section{The goals of blood pressure in the patient with diabetes and hypertension}

Hypertension is present in $20 \%$ to $60 \%$ of patients with type 2 diabetes, depending on age, ethnicity, obesity, and the presence of micro or macro albuminuria [41]. High
BP substantially increases the risk of both macro and micro vascular complications, doubling the risk of allcause mortality and stroke, tripling the risk of coronary heart disease and significantly hastening the progression of diabetic nephropathy, retinopathy, and neuropathy [41-43]. In these patients, a difference of $5 \mathrm{mmHg}$ in either systolic blood pressure (SBP) or diastolic blood pressure (DBP) increases the risk of cardiovascular events or death by $20 \%$ to $30 \%$ [44]. In observational studies, people with both diabetes and hypertension have approximately twice the risk of cardiovascular disease as no diabetic people with hypertension, and are also at increased risk for diabetes specific complications, including retinopathy and nephropathy. In the UKPDS epidemiologic analysis, for each $10 \mathrm{mmHg}$ decrease in mean SBP the estimated risk of any complication related to diabetes, deaths related to diabetes, $\mathrm{MI}$, and micro vascular complications was reduced by $12 \%, 15 \%, 11 \%$, and $13 \%$, respectively [45]. These results are in keeping with the $15 \%$ risk reduction for cardiovascular death reported in the Seven Countries Study and to the estimates of the Multiple Risk Factor Intervention Trial (MRFIT) for diabetic patients $[46,47]$. Thus, BP lowering is a major priority in preventing cardiovascular and renal events in patients with DM2 and hypertension.

During many years the BP goals recommended in patients with diabetes were more aggressive than in patients without diabetes [48-53]. Moreover, it was proposed the maximum of "the lower the better" with no threshold [53]. However, the 2009 European Society of Hypertension guidelines proposed that lowering the blood pressure to less than $130 / 80 \mathrm{mmHg}$ in patients at high risk for cardiovascular events was unsupported by prospective trial data, and that the systolic blood pressure should be lowered to less than $140 \mathrm{mmHg}$ in these patients [54]. Moreover, this reappraisal of the European guidelines addressed the issue of the so- called J-curve and the clinical implications from this phenomenon, subject that has been reviewed recently [55-58]. The recommendations suggest lowering the SBP/DBP to values within the 130-139/80- $85 \mathrm{mmHg}$ range in all hypertensive patients [54]. Several news clinical trials, including a retrospective analysis supported this recommendation. The International Verapamil SR- Trandolapril Study (INVEST) [59] in which the patients were divided into three groups depending on the achieved BP: (1) those who had not reached the control level (SBP >140 mmHg), (2) those who had reached the standard control level (SBP $<140-130 \mathrm{mmHg}$ ) and (3) those on intensive BP control (SBP $<130 \mathrm{mmHg}$ ). In patients with noncontrolled BP, the risk of death, MI or stroke was as much as 50\% higher compared to those with controlled BP (HR 1.46; $\mathrm{p}<0.0001)$. Interestingly, it was observed an increased risk of death due to any cause - about $8 \%$ after 
30 months and 5 years after the study [adjusted HR: 1.20 $(\mathrm{p}=0.06)$ and $1.15(\mathrm{p}=0.04)$, respectively] in patients with intensively controlled BP. Additional analyses revealed that this risk was caused by a higher incidence of death in patients with SBP below $115 \mathrm{mmHg}$ [59]. The Action to Control Cardiovascular Risk In Diabetes - Blood Pressure Arm (ACCORD-BP) study [44] was designed to evaluate the impact of treatment aimed at intensive lowering of SBP to $<120 \mathrm{mmHg}$ (compared to standard therapy) on the incidence of $\mathrm{CV}$ events in 4,733 DM patients. The study enrolled high-risk DM patients: aged $>40$ and with coexisting CVD; or aged $>55$ with marked atherosclerosis, albuminuria, and LVH; or with at least two risk factors for CVD: dyslipidemia, arterial hypertension, smoking or obesity. After a year of treatment, the mean SBP was $119.3 \mathrm{mmHg}$ in the group managed intensively and $133.5 \mathrm{mmHg}$ in the group on standard therapy, while the mean DBP values were 64.4 and $70.5 \mathrm{mmHg}$, respectively. The primary endpoint, comprising nonfatal MI or stroke, or death due to $\mathrm{CV}$ causes, occurred in 445 patients (1.87\% per year in the group on intensive treatment compared with $2.09 \%$ of those on standard therapy; $\mathrm{p}=0.20$ ). In addition, there were 294 deaths due to any cause $(1.28 \%$ in the intensive therapy group vs. $1.19 \%$ in the standard treatment group; $\mathrm{p}=0.55$ ) and 118 due to cardiovascular causes $(0.52 \%$ vs. $0.49 \%$, respectively; $\mathrm{p}=0.74)$. The incidence of stroke was significantly higher in the group receiving standard treatment $(0.53 \%$ vs. $0.32 \%$; $\mathrm{p}=0.01)$; a similar relationship was found for non-fatal stroke $(0.30 \%$ vs. $0.47 \% ; p=0.03)$. It was concluded that intensive hypotensive therapy did not significantly reduce the incidence of primary endpoints or the majority of secondary endpoints; however, it was associated with a significant reduction in the total number of strokes (by $41 \%$; HR 0.59 ; 95\% CI, 0.39-0.89; $\mathrm{p}=0.03$ ) and nonfatal strokes (by 37\%). In the intensive therapy group, the incidence of adverse complications of treatment (orthostatic hypotension, hyperkalemia, syncope, bradycardia, arrhythmia or renal function impairment) was significantly increased (3.3\% vs. $1.3 \%)$. Thus, the ACCORD-BP study demonstrated the importance of defines the group of patients in whom significant $\mathrm{BP}$ reduction could be particularly dangerous and, on the other hand, those with a high risk of stroke who could benefit most from an intensive hypotensive therapy. Moreover, the ACCORD-BP study confirmed that lowering SBP to below $115 \mathrm{mmHg}$ may be dangerous [44].

In the Irbesartan Diabetic Nephropathy Trial (IDNT) [60], similar results were observed where a DBP $<85 \mathrm{mmHg}$ was associated with an increase in all-cause mortality, a significant increase in MI, but a decreased risk for stroke. The Appropriate Blood Pressure Control in DiabetesNormotension (ABCD-NT) trial [61,62], a level of SBP $<130 \mathrm{mmHg}$ was not associated with a benefit in the primary outcome (renal dysfunction) or any other $\mathrm{CV}$ outcome. The active group participants did benefit from a significant reduction in stroke. This trial randomized 470 subjects with type 2 diabetes (age: 58 years; baseline BP: $155 / 98 \mathrm{mmHg}$ ) to a DBP target of either $75 \mathrm{mmHg}$ or 80 to $89 \mathrm{mmHg}$. Achieved BP was $132 / 78$ and $138 / 86 \mathrm{mmHg}$ in the intensive- and the less-intensive groups, respectively. No significant difference in any cardiovascular end points, rate of progression of renal disease, or retinopathy was reported, even if a difference in overall mortality was also evident $(6 \%$ and $11 \%$ in the intensive and lessintensive groups, respectively).

A lack of benefits of lowering the SBP level $<130 \mathrm{mmHg}$ in patients with diabetes was also observed in the recent analysis of the ONTARGET trial [63]. In this study, an increased cardiovascular mortality was observed in the presence of SBP lower than $125 \mathrm{mmHg}$, compared with SBP less than $130 \mathrm{mmHg}$. These results are consistent with the olmesartan study, wherein a SBP lower than $120 \mathrm{mmHg}$ showed a J-shaped increase of cardiovascular mortality in the olmesartan group, compared with the placebo group [64].

Vamos et al. [65] included a total of 126,092 adult patients (age $>18$ years) from the United Kingdom General Practice Research Database (UKGPRD) with a new diagnosis of type 2 diabetes. This study demonstrated not only the lack of benefits of lowering the SBP below $130 \mathrm{mmHg}$, but also the J-shaped relationship in DM patients. In patients with CVD, the tight control of SBP $(<130 \mathrm{mmHg})$ and DBP $(<80 \mathrm{mmHg})$ was not associated with improved survival.

The HOT trial included a prespecified subgroup analysis in 1,501 diabetic subjects (age: 61.5 years; baseline BP: $170 / 105 \mathrm{mmHg}$ ), randomized to three different DBP targets: 90, 85, and $80 \mathrm{mmHg}$ [66]. Achieved BP was $144 / 85,141 / 83$, and $140 / 81 \mathrm{mmHg}$ in the three target groups, respectively. A target of $80 \mathrm{mmHg}$ significantly reduced both major cardiovascular event rates (11.9/ 1,000 person-years; RR 0.49; 95\% CI, 0.29-0.81) and cardiovascular mortality (3.7/1,000 person-years; RR 0.33 ; 95\% CI, 0.14-0.78) compared with a target of $90 \mathrm{mmHg}$ (24.4/1,000 person-years and 11.1/1,000 person-years, respectively).

The results of the HOT study give place a very intensive discussion about the J-shaped existence [67-69]. As was discussed by Cooper-DeHoff et al. [57] and GarciaTouze and Sowers [70] in recently reviews, one of the main concerns on intensive BP lowering is the belief that excessive reduction of BP values, particularly diastolic, may increase the risk of MI. In diabetic patients with hypertension, two post hoc observational analyses have recently raised the issue of a J-curve effect [71,72]. In the first study [71], 6,400 patients with diabetes, CAD, and age $>50$ years, from the original 22,576 participants of the INVEST trial, were divided into three different 
groups: tight control (SBP $<130 \mathrm{mmHg}$ ), usual control (from $130 \mathrm{mmHg}$ to $<140 \mathrm{mmHg}$ ), and uncontrolled (140 $\mathrm{mmHg}$ or more). Primary outcome was the first occurrence of all-cause death, nonfatal MI, or nonfatal stroke. During 16,893 patient-years of follow-up, 286 patients (12.7\%) with tight BP control, 249 (12.6\%) with usual control, and 431 (19.8\%) with uncontrolled SBP experienced a primary outcome event. Although usual $\mathrm{BP}$ control allowed a significant reduction in the cardiovascular event rate, as compared with the uncontrolled group (12.6\% vs. $19.8 \%$; adjusted hazard ratio [HR], 1.46; 95\% CI, 1.25-1.71; $\mathrm{P}<0.001)$, little difference existed between those with usual control and those with tight control (12.6\% vs. $12.7 \%$; adjusted HR, 1.11; $95 \% \mathrm{CI}$, 0.93-1.32; $\mathrm{P}=0.24)$. In addition, all-cause mortality rate showed a no statistically significant trend toward a higher risk in the tight-control group, as compared with the usual control group ( $11 \%$ vs. $10.2 \% ; \mathrm{P}=0.06)$, that became statistically significant when the extended follow-up was included ( 22.8 vs. $21.8 \%$; $\mathrm{P}=0.04$ ). A major limitation of the latter finding was the fact that no BP data were collected during the extended follow-up [73].

In the second study, a post hoc observational analysis on the diabetic patients of the UKPDS [72] investigators randomly assigned patients with diabetes to either 'tight BP control' $(<150 / 85 \mathrm{mmHg})$ or 'less-tight BP control' $(<180 / 105 \mathrm{mmHg})$. Patients in the $<150 / 85 \mathrm{mmHg}$ group had a mean baseline BP of $159 / 94 \mathrm{mmHg}$ and achieved a mean BP of $144 / 82 \mathrm{mmHg}$, whereas those in the $<180 / 105 \mathrm{mmHg}$ group had a mean baseline BP of $160 / 94 \mathrm{mmHg}$ and achieved a mean BP of $154 / 87 \mathrm{mmHg}$ after more than 8 years of follow- up. Compared with the less-tight-control group, those in the tight-control group had a significant $44 \%$ reduction in risk of stroke $(P=0.013)$, a $32 \%$ reduction in risk of diabetes- related death $(\mathrm{P}=0.019)$, and a $24 \%$ reduction in risk of diabetes-related end points $(\mathrm{P}=0.0046)$. When the UKPDS investigators performed an additional 10-year follow-up of the patients [73], which included in-person visits and questionnaires but no attempt to intervene on BP, the benefits observed in the tight-control group at the first 8-year follow-up were no longer present. Over the entire 20-year follow-up period, no difference in the rate of any diabetes-related end points, MI, microvascular disease, or all-cause mortality was observed between the tightcontrol and less-tight-control groups [73]. The Table 1 summarizes the main results of the clinical trials about discussed.

We refer the above-cited reviews $[56,57,70]$ for the explanation of the pathophysiologic interpretation of the J-curve that lies in the mechanisms of coronary artery perfusion, which depends on the pressure gradient between the coronary arteries and the left ventricle during the diastolic phase of the cardiac cycle. However, the concept of a
J-curve has been challenged by several observational studies and randomized controlled trials, in which the J-curve effect was not clearly evident. In addition, other explanations about the finding of a J-curve have been proposed; in particular, reverse causality views coexisting in chronic diseases or poor health conditions as a cause for concomitant low DBP, which could lead to a spurious association with increased morbidity and mortality.

Chronic kidney disease (CKD), defined by a reduced glomerular filtration rate (GFR) is common in subjects with DM2 and hypertension [74,75]. Nowadays CKD is affecting $10-15 \%$ of the adult general population and it is associated with an increased risk of CVD [76]. Guidelines recommended lower BP targets in this population than in people without CKD [77]. Moreover, it has been suggested that the inhibitors of the RAAS have particular benefits for the prevention of renal complication [78]. A recent meta-analysis of randomized controlled trials [79] that included 25 trials and 152,290 individuals showed that BP lowering regimens in relation to placebo reduced the risk of mayor $\mathrm{CV}$ events in individuals with and without reduced GFR with no evidence for any difference in effect. The results were similar irrespective of whether BP was reduced by regimens based on different antihypertensive drugs. This meta-analysis provides clean evidence that a broad range of different BP lowering regiments provide protection against CVD in patient with CKD. However, the results of the ONTARGET trial [21] and of the VA NEPHRON study [80] have clearly demonstrated that the combination of an ACEI plus an ARB not is recommend because of the increased risk of adverse events among patients with diabetic nephropathy. Moreover, as revised by $\mathrm{Wu}$ et al. [22], two large scale placebo controlled trials for diabetic nephropathy using the ARBs Irbesartan and Olmesartan $[81,82]$ have shown a higher rate of $\mathrm{CV}$ death among patients randomized to the $\mathrm{ARB}$ group. On the other hand, the ONTARGET trial $[21,83]$ using the ARB Telmisartan and the ACEI ramipril, showed equivalent cardioprotective effects of both RAAS blockers in patients with high risk of CVD or DM2. Nevertheless, participants in this trial were not randomized based on the presence of DM2 or the severity of nephropathy. The meta-analysis of $\mathrm{Wu}$ [22] concludes that since there is no evidence to show a better protective effect for ARBs compared with ACEI, the use of ACEI is recommended when cost is a concern.

\section{Conclusions}

The importance of $\mathrm{BP}$ as a modifiable risk factor for CVD, especially in patients with diabetes is well recognized, and many effective and inexpensive BP-lowering treatments are commonly available. The recent Latin American (1) and European (2) guidelines, published this year has recommended as a goal for the blood pressure 
Table 1 Studies addressing the definition of the goal of blood pressure control in patients with diabetes and hypertension

\begin{tabular}{|c|c|c|c|c|c|c|}
\hline Study & Ref & $\begin{array}{l}\text { Number of } \\
\text { subjects }\end{array}$ & Design & $\begin{array}{l}\text { BP }(\mathrm{mmHg}) \text { target } \\
\text { by groups }\end{array}$ & $\begin{array}{l}\mathrm{BP}(\mathrm{mmHg}) \\
\text { achieved }\end{array}$ & Main results \\
\hline \multirow[t]{3}{*}{ INVEST } & \multirow[t]{3}{*}{58} & \multirow[t]{3}{*}{6,400} & \multirow{3}{*}{$\begin{array}{l}\text { Observational } \\
\text { subgroup analysis }\end{array}$} & Group 1. SBP <140 & Group 1. 159/86 & \multirow{2}{*}{$\begin{array}{l}\text { Group } 1 \text { have } 50 \% \text { higher risk of death, } \\
\text { Ml, or stroke }(P<0.0001) \text {. Group } 3 \text { in } \\
\text { relation to group } 2 \text { have an increase of } \\
8 \% \text { of CVD after } 5 \text { years of study }(p<0.04)\end{array}$} \\
\hline & & & & Group 2. SBP $<140-130$ & Group 2. 149/85 & \\
\hline & & & & Group 3. SBP<130 & Group 3. 144/85 & $\begin{array}{l}\text { Higher incidence of death in patients } \\
\text { with } \mathrm{SBP}<115 \text {. }\end{array}$ \\
\hline \multirow[t]{2}{*}{ ACCORD-BP } & \multirow[t]{2}{*}{43} & \multirow[t]{2}{*}{4,733} & \multirow[t]{2}{*}{$\begin{array}{l}\text { Randomized } \\
\text { clinical trial (RCT) }\end{array}$} & $\begin{array}{l}\text { Group 1. Intensive } \\
\text { SBP }<120\end{array}$ & Group 1. 119.3/64.4 & \multirow{2}{*}{$\begin{array}{l}\text { No differences in the primary end point } \\
\text { (Ml, stroke and CV death) or in death } \\
\text { due to any cause. Higher incidence of } \\
\text { stroke ( } p=0.01 \text { ) or non-fatal stroke } \\
\text { ( } p=0.03) \text {. Increase of adverse events } \\
\text { in group 1. }\end{array}$} \\
\hline & & & & $\begin{array}{l}\text { Group 2. Standard } \\
\text { SBP }<140\end{array}$ & Group 2. 133.5/70.5 & \\
\hline
\end{tabular}

\begin{tabular}{lllll}
\hline IDN-T & 59 & 1,590 & Post hoc analysis & $\leq 135 / 85$
\end{tabular} 30\% reach the SBP goal Progressively lower achieved SBP to 120
and $81 \%$ the DBP goal predicted a decrease in CV mortality and CHF but not MI. A SBP $<120$ was associated with increased $C V$ deaths and CHF events. $\mathrm{DBP}<85$ was associated with increase of all-cause mortality, Ml mortality but decrease risk of stroke.

\begin{tabular}{|c|c|c|c|c|c|c|}
\hline \multirow[t]{2}{*}{ ABCD-NT } & \multirow[t]{2}{*}{60,61} & \multirow[t]{2}{*}{470} & \multirow[t]{2}{*}{$\mathrm{RCT}$} & \multirow{2}{*}{$\begin{array}{l}\text { Group 1. DBP }<75-79 \\
\text { Group 2. DBP 80-89 }\end{array}$} & \multirow{2}{*}{$\begin{array}{l}132 / 78 \\
138 / 86\end{array}$} & \multirow{2}{*}{$\begin{array}{l}\text { No differences in any CV events, or } \\
\text { progression of renal disease, nor } \\
\text { retinopathy. }\end{array}$} \\
\hline & & & & & & \\
\hline \multirow[t]{4}{*}{ ONTARGET } & \multirow[t]{4}{*}{62} & \multirow[t]{4}{*}{9,603} & \multirow[t]{4}{*}{ Post hoc analysis } & Group 1. SBP 95-130 & 125.8 SD 12.0 & \multirow{4}{*}{$\begin{array}{l}\text { Increased } C V \text { mortality with } \mathrm{SBP}<125 \text { in } \\
\text { relation with } \mathrm{SBP}<130 \text {. }\end{array}$} \\
\hline & & & & Group 2. SBP 131-142 & 132.4 SD 11.2 & \\
\hline & & & & Group 3. SBP 143-154 & 137.7 SD 11.5 & \\
\hline & & & & Group 4. SBP 155-200 & 144.3 SD 12.6 & \\
\hline \multirow[t]{2}{*}{ ROADMAP } & \multirow[t]{2}{*}{63} & \multirow[t]{2}{*}{4,447} & \multirow[t]{2}{*}{$\mathrm{RCT}$} & Group 1. SBP $<130$ & \multirow{2}{*}{$\begin{array}{l}80 \% \text { achieved } \\
\text { the target }\end{array}$} & \multirow{2}{*}{$\begin{array}{l}\text { SBP }<120 \text { showed a J-shaped increase of } \\
\text { CV mortality. }\end{array}$} \\
\hline & & & & Group 2. $\mathrm{DBP}<80$ & & \\
\hline \multirow[t]{7}{*}{ UKGPRD } & \multirow[t]{7}{*}{64} & 126,092 & \multirow[t]{7}{*}{ Retrospective study } & Group 1. $<130 /<80$ & Achieved target & \multirow{7}{*}{$\begin{array}{l}\text { J-shaped relationship in patients with } \\
\mathrm{SBP}<130 \text { In patients with CVD SBP }<130 \\
\text { and } \mathrm{DBP}<80 \text { was not associated with } \\
\text { improved survival. BP }<110 / 75 \text { increase } \\
\text { the risk of CV mortality. }\end{array}$} \\
\hline & & \multirow{6}{*}{$\begin{array}{l}12,379 \\
\text { with CVD }\end{array}$} & & Group 2. 130-139/80-<85 & Group 1. SBP18.1\% & \\
\hline & & & & Group 3. $\geq 140 / \geq 85$ & DBP $35.7 \%$ & \\
\hline & & & & & Group 2. SBP 19.9\% & \\
\hline & & & & & DBP $27.7 \%$ & \\
\hline & & & & & Group 3. SBP $61 \%$ & \\
\hline & & & & & DBP $36.6 \%$ & \\
\hline \multirow[t]{3}{*}{$\overline{\mathrm{HOT}}$} & \multirow[t]{3}{*}{65} & \multirow[t]{3}{*}{1,501} & \multirow[t]{3}{*}{$\mathrm{RCT}$} & Group 1. DBP $<90$ & Group 1. 144/85 & \multirow{3}{*}{$\begin{array}{l}\mathrm{DBP}<80 \text { showed a significantly reduction } \\
\text { in } \mathrm{CV} \text { events and } \mathrm{CV} \text { mortality. }\end{array}$} \\
\hline & & & & Group 2. $\mathrm{DBP}<85$ & Group2. 141/83 & \\
\hline & & & & Group 3. DBP $<80$ & Group 3. $140 / 81$ & \\
\hline \multirow[t]{2}{*}{ UKPDS } & \multirow[t]{2}{*}{71} & \multirow[t]{2}{*}{4,801} & \multirow{2}{*}{$\begin{array}{l}\text { Post hoc } \\
\text { observational } \\
\text { analysis }\end{array}$} & Group 1.<150/85 & Group 1. 144/82 & \multirow{2}{*}{$\begin{array}{l}\text { Group } 1 \text { had a significant } 44 \% \text { reduction } \\
\text { of stroke, } 32 \% \text { of diabetes related death, } \\
24 \% \text { diabetes related end patients. }\end{array}$} \\
\hline & & & & Group 2. <180/105 & Group 2. 154/87 & \\
\hline
\end{tabular}

$\mathrm{BP}=$ blood pressure, $\mathrm{SBP}=$ systolic $\mathrm{BP}, \mathrm{DBP}=$ diastolic $\mathrm{BP}, \mathrm{Ml}=$ myocardial infarction, $\mathrm{CVD}=$ cardiovascular diseases $\mathrm{CV}=$ cardiovascular, $\mathrm{CHF}=$ congestive heart failure.

control in patients with diabetes type 2 a value similar or inferior to $140 / 90 \mathrm{mmHg}$. Therefore, BP control and prevention of related morbidity and mortality is clearly achievable. However, the awareness, treatment and control of hypertension are low worldwide. The big challenge now is avoid the therapeutic inertia (leaving diabetic patients with $\mathrm{BP}$ values of $140 / 90 \mathrm{mmHg}$ or higher) at all costs, as this would lead to an unacceptable toll in terms of human lives, suffering, and socioeconomic costs. The health team and the subjects affected of hypertension and diabetes must to participate actively in the challenge to pass from the guidelines recommendations to the clinical practice and public health programs, to improve the percentage of control of high BP. Moreover, the development of research aimed to evaluate new approaches to effectively diagnostic, treated and control high BP is a priority [84]. 


\section{Abbreviations}

ABCD-NT: Appropriate blood pressure control in diabetes-normotension trial; ACCORD-BP: Action to control cardiovascular risk in diabetes - blood pressure arm; BP: Blood pressure; BPLTTC: Blood pressure lowering treatment trialists collaboration; CAD: Coronary artery disease; DBP: Diastolic blood pressure; CVD: Cardio vascular diseases; DALY: Disability adjusted life years; DIAD: Detection of ischaemia in asymptomatic diabetics study; DM2: Diabetes type 2; DR: Diabetes retinopathy; HIC: High income countries; HOT: Hypertension optimal treatment trial; IDNT: Irbesartan diabetic nephropaty trial; IHD: Ischemic heart disease; INVEST: International verapamil SR-trandolapril study; LIC: Low income countries; LMIC: Low middle income countries; MI: Myocardial infarction; MIC: Middle income countries; MRFIT: Multiple risk factor intervention trial; ONTARGET: Ongoing telmisartan alone and in combination with ramipril global endpoint trial; PURE: Prospective urban rural epidemiology; RASS: Renin-angiotensin-aldosterone system; SBP: Systolic blood pressure; UKPDS: United Kingdom Prospective Diabetes Study; UMIC: Upper middle income countries.

\section{Competing interests}

The authors declare that they have no competing interests.

\section{Authors' contributions}

$P L-J$ and IR-A conceive and design the manuscript $J-L$ and $C L-L$ participate in acquisition of data. All authors have been involved in drafting the manuscript and have given final approval of the version to be published.

\section{Author details}

${ }^{1}$ Research Institute and Clinic of Diabetes and Metabolic Syndrome, Fundación Oftalmológica de Santander (FOSCAL), Calle 155 A No 23-09, Torre Milton Salazar, Urbanizacion El Bosque, Floridablanca, Santander, Colombia. ${ }^{2}$ MASIRA Research Institute, Medical School, Universidad de Santander (UDES), Bucaramanga, Colombia. ${ }^{3}$ Medical School, Universidad Autonoma de Bucaramanga (UNAB), Bucaramanga, Colombia.

\section{Received: 6 September 2013 Accepted: 22 February 2014}

Published: 4 March 2014

\section{References}

1. Lopez-Jaramillo P, Sanchez R, Diaz M, Cobos L, Bryce A, Parra-Carrillo JZ, Lizcano F, Lanas F, Sinay I, Sierra IV, Penaherrera E, Bendersky M, Schmid H, Botero R, Urina M, Lara J, Foss MC, Matquez G, Harrap S, Ramorez AJ, Zanchetti A, on behalf of the Latin America expert Group: Latin American consensus on hypertension in patients with diabetes type 2 and metabolic syndrome. J Hypertens 2013, 31:223-238.

2. Mancia G, Fagard R, Narkiewicz K, Redon J, Zanchetti A, Bohm M, Christiaens T, Cifkvra R, De Backer G, Dominiczak A, Galdereisi M, Grobbeee DE, Jaarsma T, Kirchhof P, Kjeldsen SE, Laurent S, Manolis AJ, Nilsson PM, Ruilope LM, Schmieder RE, Sirnes PA, Sleight P, Viigimaa M, Waeber B, Zannad F: ESH/ESC Guidelines for the management of arterial hypertension; The Task Force for the management of arterial hypertension of the European Society of Hypertension (ESH) and of the European Society of Cardiology (ESC). J Hypertens 2013, 2013 (31):1281-1357.

3. American Diabetes Association: Standards of medical care in diabetes2013. Diabetes Care 2013, 36(Suppl 1):S11-S66.

4. Yusuf S, Hawken S, Ounpuu S, Dans T, Avezum A, Lanas F, McQueen M, Budaj A, Pais P, Varigos J, Lisheng L: Effect of potentially modifiable risk factors associated with myocardial infarction in 52 countries (the INTERHEART study): case-control study. Lancet 2004, 364:937-952.

5. O'Donnell MJ, Xavier D, Liu L, Zhang H, Chin SL, Rao-Melacini P, Rangarajan S, Islam S, Pais P, McQueen MJ, Mondo C, Damasceno A, Lopez-Jaramillo P, Hankey GJ, Dans AL, Yusoff K, Truelsen T, Diener HC, Sacco RL, Ryglewicz D, Czlonkowska A, Weimar C, Wang X, Yusuf S, INTERSTROKE investigators: Risk factors for ischemic and intracerebral haemorragic stroke in 22 countries (the INTERSTROKE study): a case-control study. Lancet 2010, 376:112-123.

6. Chow CK, Teo KK, Rangarajan S, Islam S, Gupta R, Avezum A, Bahonar A, Jephat Chifamba J, Dagenais G, Diaz R, Kazmi K, Lanas F, Wei L, LopezJaramillo P, Fanghong L, Noorhassim I, Puoane T, Rosengren A, Szuba A, Temizhan A, Wielgosz A, Yusuf R, Yusufali A, McKee M, Lisheng L, Mony P, Yusuf S, on behalf of the PURE (Prospective Urban Rural Epidemiology) Study investigators: Prevalence, awareness, treatment and control of hypertension in 628 rural and urban communities from 17 high, middle and low income countries: results from the PURE (Prospective Urban Rural Epidemiology) study. JAMA 2013, 310:959-968.

7. Mathers C, Stevens G, Mascarenhas M: Global Health Risks: Mortality and Burden of Disease Attributable to Selected Major Risk Factors. Geneva: World Health Organization; 2009.

8. Rodgers A, Ezzati M, Vander Hoorn S, Lopez AD, Lin RB, Murray CJ: Distribution of major health risks: findings from the Global Burden of Disease study. PLOS Med 2004, 1:e27.

9. Yusuf S, Reddy S, Ônpuu S, Anand S: Global burden of cardiovascular diseases part II: variations in cardiovascular disease by specific ethnic groups and geographic regions and prevention strategies. Circulation 2001, 104:2855-2864.

10. Reddy KS, Yusuf S: Emerging epidemic of cardiovascular disease in developing countries. Circulation 1998, 97:596-601.

11. Whelton PK, Brancati FL, Appel $L$, Klag MJ: The challenge of hypertension and atherosclerotic cardiovascular disease in economically developing countries. High Blood Press 1995, 4:36-45.

12. Yusuf S, Reddy S, Ônpuu S, Anand S: Global burden of cardiovascular diseases: part I: general considerations, the epidemiologic transition, risk factors, and impact of urbanization. Circulation 2001, 104:2746-2753.

13. Beaglehole R, Bonita R, Horton R, Adams C, Alleyne G, Asaria P, Baugh V, Bekedam H, Billo N, Casswell S, Cecchini M, Colagiuri R, Colagiuri S, Collins T, Ebrahim S, Engelgau M, Galea G, Gaziano T, Geneau R, Haines A, Hospedales J, Jha P, Keeling A, Leeder S, Lincoln P, McKee M, Mackay J, Magnusson R, Moodie R, Mwatsama M, et al: Priority actions for the non- communicable disease crisis. Lancet 2011, 377:1438-1447.

14. Lawes CMM, Hoorn SV, Rodgers A: Global burden of blood-pressure-related disease, 2001. Lancet 2008, 371:1513-1518.

15. He J, Gu D, Chen J, Wu X, Kelly TN, Huang JF, Chen JC, Chen CS, Bazzano LA, Reynolds K, Whelton PK, Klag MJ: Premature deaths attributable to blood pressure in China: a prospective cohort study. Lancet 2009, 374:1765-1772.

16. MacMahon S, Alderman MH, Lindholm LH, Liu L, Sanchez RA, Seedat YK Blood- pressure-related disease is a global health priority. Lancet 2008 371:1480-1482.

17. Gaziano TA: Accurate hypertension diagnosis is key in efficient control. Lancet 2011, 378:1199-2000.

18. Turnbull F: Blood Pressure Lowering Treatment Trialists' Collaboration Effects of different blood pressure-lowering regimens on major cardiovascular events: results of prospectively designed overviews of randomised trials. Lancet 2003, 362:15271535.

19. Viana LV, Leitão CB, Grillo MF, Rocha EP, Brenner JK, Friedman R, Gross JL: Hypertension management algorithm for type 2 diabetic patients applied in primary care. Diabetol Metab Syndr 2013, 5:52. doi:10.1186/17585996-5-52

20. Yusuf S, Sleight P, Pogue J, Bosch J, Davies R, Dagenais G: Effects of an angiotensinconverting-enzyme inhibitor, ramipril, on cardiovascular events in high-risk patients. The Heart Outcomes Prevention Evaluation Study Investigators. N Engl J Med 2000, 342:145-153.

21. Investigators ONTARGET, Yusuf S, Teo KK, Pogue J, Dyal L, Copland I, Schumacher H, Dagenais G, Sleight P, Anderson C: Telmisartan, ramipril, or both in patients at high risk for vascular events. N Engl J Med 2008, 358:1547-1559.

22. Wu H-Y, Huang J-W, Lin H-J, Liao W-C, Peng $Y-S$, Hung $K-Y$, Wu K-D, Tu Y-K, Chien K-L: Comparative effectiveness of renin-angiotensin system blockers and other antihypertensive drugs in patients with diabetes: systematic review and Bayesian network meta-analysis. BMJ 2013, 347:f6008. doi:10.1136/bmj.f6008 (Published 24 October 2013).

23. Stratton IM, Adler Al, Neil HA, Matthews DR, Manley SE, Cull CA, Hadden D, Turner RC, Holman RR: Association of glycaemia with macrovascular and microvascular complications of type 2 diabetes (UKPDS 35): prospective observational study. BMJ 2000, 321:405-412.

24. Expert Committee on the Diagnosis and Classification of Diabetes Mellitus: Report of the Expert Committee on the Diagnosis and Classification of Diabetes Mellitus. Diabetes Care 1997, 20:1183-1197.

25. Huxley R, Barzi F, Woodward M: Excess risk of fatal coronary heart disease associated with diabetes in men and women: meta-analysis of 37 prospective cohort studies. BMJ 2006, 332:73-78.

26. UK Prospective Diabetes Study (UKPDS) Group: Intensive blood- glucose control with sulphonylureas or insulin compared with conventional 
treatment and risk of complications in patients with type 2 diabetes (UKPDS 33). Lancet 1998, 352:83785.

27. Sung J, Song YM, Ebrahim S, Lawlor D: Fasting blood glucose and the risk of stroke and myocardial infarction. Circulation 2009, 119:812-819.

28. UK Prospective Diabetes Study (UKPDS) Group: Effect of intensive blood glucose control with metformin on complications in overweight patients with type 2 diabetes (UKPDS 34). Lancet 1998, 352:854-865.

29. Holman RR, Paul SK, Bethel MA, Matthews DR, Neil HA: 10-Year follow-up of intensive glucose control in type 2 diabetes. N Engl J Med 2008, 359:1577-1589.

30. Cosson E, Attali JR, Valensi P: Markers for silent myocardial ischemia in diabetes. Are they helpful? Diabetes Metab 2005, 31:205-213.

31. Garcia RG, Lopez-Jaramillo P: Cardiovascular prevention in high-risk patients with type 2 diabetes mellitus: when to start it? Eur Hearth $J$ 2008, 29:2058-2059.

32. Libby P: Mechanisms of acute coronary syndromes and their implications for therapy. N Engl J Med 2013, 368:2004-2013.

33. Gomez-Arbelaez D, Lopez-Jaramillo P: Mechanism of acute coronary syndromes. N Engl J Med 2013, 369:882-884.

34. Wackers FJ, Young LH, Inzucchi SE, Chyun DA, Davey JA, Barrett EJ, Taillefer R, Wittlin SD, Heller GV, Filipchuk N, Engel S, Ratner RE, Iskandrian $A E$, Detection of Ischemia in Asymptomatic Diabetics Investigators: Detection of Silent Myocardial Ischemia in Asymptomatic Diabetic Subjects. The DIAD Study. Diabetes Care 2004, 27:1954-1961.

35. Hernández C, Candell-Riera J, Ciudin A, Francisco G, Aguadé-Bruix S, Simó R: Prevalence and risk factors accounting for true silent myocardial ischemia: a pilot case-control study comparing type 2 diabetic with non-diabetic control subjects. Cardiovasc Diabetol 2011, 10:9.

36. Cheung N, Wang JJ, Klein R, Couper DJ, Sharrett AR, Wong TY: Diabetic retinopathy and the risk of coronary heart disease: the atherosclerosis risk in communities study. Diabetes Care 2007, 30:1742-1746.

37. Juutilainen A, Lehto S, Rönnemaa T, Pyörälä K, Laakso M: Retinopathy predicts cardiovascular mortality in type 2 diabetic men and women. Diabetes Care 2007, 30:292-299.

38. Kramer CK, Rodrigues TC, Canani LH, Gross JL, Azevedo MJ: Diabetic retinopathy predicts all-cause mortality and cardiovascular events in both type 1 and 2 diabetes: meta-analysis of observational studies. Diabetes Care 2011, 34:1238-1244.

39. Lopez-Jaramillo P, Lahera V, Lopez-Lopez J: Epidemic of cardiometabolic diseases: a Latin American point of view. Ther Adv Cardiovas Dis 2011, 5:119-131.

40. Wackers FJ, Chyun DA, Young LH, Heller GV, Iskandrian AE, Davey JA, Barrett EJ, Taillefer R, Wittlin SD, Filipchuk N, Ratner RE, Inzucchi SE, Detection of Ischemia in Asymptomatic Diabetics (DIAD) Investigators: Resolution of asymptomatic myocardial ischemia in patients with type 2 diabetes in the Detection of Ischemia in Asymptomatic Diabetics (DIAD) study. Diabetes Care 2007, 30:2892-2898.

41. Kannel WB, Wilson PW, Zhang TJ: The epidemiology of impaired glucose tolerance and hypertension. Am Heart J 1991, 121:1268-1273.

42. Stamler J, Vaccaro O, Neaton JD, Wentworth D: Diabetes, other risk factors, and 12- yr cardiovascular mortality for men screened in the Multiple Risk Factor Intervention Trial. Diabetes Care 1993, 16:434-444.

43. Sowers JR, Epstein M, Frohlich ED: Diabetes, hypertension, and cardiovascular disease: an update. Hypertension 2001, 37:1053-1059

44. ACCORD Study Group, Cushman WC, Evans GW, Byington RP, Goff DC Jr, Grimm RH Jr, Cutler JA, Simons-Morton DG, Basile JN, Corson MA, Probstfield JL, Katz L, Peterson KA, Friedewald WT, Buse JB, Bigger JT, Gerstein HC, Ismail-Beigi F: Effects of intensive blood-pressure control in type 2 diabetes mellitus. N Engl J Med 2010, 362:1575-1585.

45. UK Prospective Diabetes Study Group: Tight blood pressure control and risk of macrovascular and microvascular complications in type 2 diabetes: UKPDS 38. BMJ 1998, 317:703-713.

46. Menotti A, Keys A, Blackburn H, Karvonen M, Punsar S, Nissinen A, Pekkanen J, Kromhout D, Giampaoli S, Seccareccia F: Blood pressure changes as predictors of future mortality in the seven countries study. J Hum Hypertens 1991, 5:137-144

47. Vaccaro O, Stamler J, Neaton JD: Sixteen-year coronary mortality in black and white men with diabetes screened for the Multiple Risk Factor Intervention Trial (MRFIT). Int J Epidemiol 1998, 27:636-641.
48. Carey RM, Cutler J, Friedewald W, Gant N, Hulley S, lacono J, Maxwell M, McNellis D, Payne G, Shapiro A, Weiss S, Dustan HP, Chobanian AV, Falker B, Ferris TF, Frohlich ED, Giffor RW Jr, Hill MN, Ibrahim M, Kaplan NM, Lomg O, Metcalf H, Moser M, Nickey WA, Perry HM Jr, Thomson G, Horan M, Roccella EJ, Bowler A, Gillen FW: The 1984 Report of the Joint National Committee on Detection, Evaluation, and Treatment of High Blood Pressure. Arch Intern Med 1984, 144:1045-1057.

49. Fifth Join National Committee: The fifth report of the Joint National Committee on Detection, Evaluation, and Treatment of High Blood Pressure (JNC V). Arch Intern Med 1993, 153:154-183.

50. Sixth Join National Committee: The sixth report of the Joint National Committee on Prevention, Detection, Evaluation, and Treatment of High Blood Pressure. Arch Intern Med 1997, 157:2413-2446.

51. Chobanian AV, Bakris GL, Black HR, Cushman WC, Green LA, Izzo JL Jr, Jones DW, Materson BJ, Oparil S, Wright JT Jr, Roccella EJ, National Heart, Lung, and:Blood Institute Joint National Committee on Prevention, Detection, Evaluation, and Treatment of High Blood Pressure; National High Blood Pressure Education Program Coordinating Committee: The Seventh Report of the Joint National Committee on Prevention, Detection, Evaluation, and Treatment of High Blood Pressure: the JNC 7 report. JAMA 2003, 289:2560-2572.

52. Mancia G, De Backer G, Dominiczak A, Cifkova R, Fagard R, Germano G, Grassi G, Heagerty AM, Kjeldsen SE, Laurent S, Narkiewicz K, Ruilope L, Rynkiewicz A, Schmieder RE, Struijker Boudier HA, Zanchetti A, Vahanian A, Camm J, De Caterina R, Dean V, Dickstein K, Filippatos G, Funck-Brentano C, Hellemans I, Kristensen SD, McGregor K, Sechtem U, Silber S, Tendera M, Widimsky P, et al: 2007 Guidelines for the management of arterial hypertension: The Task Force for the Management of Arterial Hypertension of the European Society of Hypertension (ESH) and of the European Society of Cardiology (ESC). Eur Heart J 2007, 2007(28):1462-1536.

53. American Diabetes Association: Treatment of hypertension in adults with diabetes. Diabetes Care 2002, 25:199-201.

54. Mancia G, Laurent S, Agabiti-Rosei E, Ambrosioni E, Burnier M, Caulfield MJ, Cifkova R, Clément D, Coca A, Dominiczak A, Erdine S, Fagard R, Farsang C, Grassi G, Haller H, Heagerty A, Kjeldsen SE, Kiowski W, Mallion JM, Manolis A, Narkiewicz K, Nilsson P, Olsen MH, Rahn KH, Redon J, Rodicio J, Ruilope L, Schmieder RE, Struijker-Boudier HA, Van Zwieten PA, et al: Reappraisal of European guidelines on hypertension management: a European Society of Hypertension Task Force document. J Hypertens 2009, 27:2121-58.

55. Banach M, Kjeldsen SE, Narkiewicz K: Editorial. Controversies in hypertension treatment. Curr Vasc Pharmacol 2010, 8:731-732.

56. Banach M, Aronow WS: Blood Pressure J-Curve. Current Concepts Curr Hypertens Rep 2012, 14:556-566.

57. Cooper-DeHoff RM, Egelund EF, Pepine CJ: Blood pressure lowering in patients with diabetes_one level might not fit all. Nat Rev Cardiol 2011, 8:42-49.

58. Aronow WS: Editorial on hemoglobin A1c, blood pressure, and low- density lipoprotein cholesterol goals in diabetics. World J Cardiol 2013, 5:119-123.

59. Cooper-DeHoff RM, Gong Y, Handberg EM, Bavry AA, Denardo SJ, Bakris GL, Pepine CJ: Tight blood pressure control and cardiovascular outcomes among hypertensive patients with diabetes and coronary artery disease. JAMA 2010, 304:61-68.

60. Berl T, Hunsicker LG, Lewis JB, Pfeffer MA, Porush JG, Rouleau JL, Drury PL, Esmatjes E, Hricik D, Pohl M, Raz I, Vanhille P, Wiegmann TB, Wolfe BM, Locatelli F, Goldhaber SZ, Lewis EJ, Collaborative Study Group: Impact of achieved blood pressure on cardiovascular outcomes in the Irbesartan Diabetic Nephropathy Trial. J Am Soc Nephrol 2005, 16:2170-2179.

61. Schrier RW, Estacio RO, Jeffers B: Appropriate Blood Pressure Control in NIDDM (ABCD) Trial. Diabetologia 1996, 39:1646-1654.

62. Schrier RW, Estacio RO, Esler A, Mehler P: Effects of aggressive blood pressure control in normotensive type 2 diabetic patients on albuminuria, retinopathy and strokes. Kidney Int 2002, 61:1086-1097.

63. Redon J, Mancia G, Sleight P, Schumacher H, Gao P, Pogue J, Fagard R, Verdecchia P, Weber M, Böhm M, Williams B, Yusoff K, Teo K, Yusuf S, ONTARGET Investigators: Safety and efficacy of low blood pressures among patients with diabetes: subgroup analyses from the ONTARGET (ONgoing Telmisartan Alone and in combination with Ramipril Global Endpoint Trial). J Am Coll Cardiol 2012, 59:74-83.

64. Haller H, Ito S, Izzo JL Jr, Januszewicz A, Katayama S, Menne J, Mimran A, Rabelink TJ, Ritz E, Ruilope LM, Rump LC, Viberti G, ROADMAP Trial 
Investigators: Olmesartan for delay or prevention of microalbuminuria in type 2 diabetes. N Engl J Med 2011, 364:907-917.

65. Vamos EP, Harris M, Millett C, Pape UJ, Khunti K, Curcin V, Molokhia M, Majeed A: Association of systolic and diastolic blood pressure and all cause mortality in people with newly diagnosed type 2 diabetes: retrospective cohort study. BMJ 2012, 345:e5567.

66. Hansson L, Zanchetti A, Carruthers SG, Dahlöf B, Elmfeldt D, Julius S, Menard J, Rahn KH, Wedel H, Westerling S: Effects of intensive blood-pressure lowering and low- dose aspirin in patients with hypertension: principal results of the Hypertension Optimal Treatment (HOT) randomised trial. HOT Study Group. Lancet 1998, 351:1755-1762.

67. Farnett L, Mulrow CD, Linn WD, Lucey CR, Tuley MR: The J-curve phenomenon and the treatment of hypertension. Is there a point beyond which pressure reduction is dangerous? JAMA 1991, 265:489-495.

68. Grossman E: Does the 'J-curve' still hold in the post 'HOT' era? J Hum Hypertens 1998, 12:729-730.

69. Ibsen $\mathrm{H}$ : Intensive blood pressure lowering warranted. Results of the HOT study: an epitaph for the J-curve concept in hypertension. J Hum Hypertens 1998, 12:731732

70. Garcia-Touza M, Sowers JR: Evidence based hypertension treatment in patients with diabetes. J Clin Hypertens (Greenwich) 2012, 14:97-102.

71. Bakris GL, Gaxiola E, Messerli FH, Mancia G, Erdine S, Cooper-DeHoff R, Pepine CJ, INVEST Investigators: Clinical outcomes in the diabetes cohort of the International Verapamil SR- Trandolapril study. Hypertension 2004, 44:637-642.

72. Adler Al, Stratton IM, Neil HA, Yudkin JS, Matthews DR, Cull CA, Wright AD, Turner RC, Holman RR: Association of systolic blood pressure with macrovascular and microvascular complications of type 2 diabetes (UKPDS 36): prospective observational study. BMJ 2000, 321:412-419.

73. Holman RR, Paul SK, Bethel MA, Neil HA, Matthews DR: Long-term follow-up after tight control of blood pressure in type 2 diabetes. N Engl J Med 2008, 359:15651576.

74. So WY, Kong AP, Ma RC, Ozaki R, Szeto CC, Chan NN, Ng V, Ho CS, Lam CW, Chow CC, Cockram CS, Chan JC, Tong PC: Glomerular filtration rate, cardiorenal end points, and all-cause mortality in type 2 diabetic patients. Diabetes Care 2006, 29:2046-2052.

75. Mahmoodi BK, Matsushita K, Woodward M, Blankestijn PJ, Cirillo M, Ohkubo T, Rossing P, Sarnak MJ, Stengel B, Yamagishi K, Yamashita K, Zhang L, Coresh J, de Jong PE, Astor BC: Chronic Kidney Disease Prognosis Consortium: Associations of kidney disease measures with mortality and end-stage renal disease in individuals with and without hypertension: a meta-analysis. Lancet 2012, 380:1649-1661.

76. Go AS, Chertow GM, Fan D, McCulloch CE, Hsu CY: Chronic kidney disease and the risks of death, cardiovascular events, and hospitalization. N Engl J Med 2004, 351:1296-1305.

77. National Kidney Foundation: K/DOQI Clinical Practice Guidelines for Chronic kidney disease. Evaluation, classification, and stratification. Am J Kidney Dis 2002, 39:S1-S266.

78. Strippoli GF, Bonifati C, Craig M, Navaneethan SD, Craig JC: Angiotensin converting enzyme inhibitors and angiotensin II receptor antagonists for preventing the progression of diabetic kidney disease. Cochrane Database Syst Rev 2006, 18, CD006257.

79. Blood Pressure Lowering Treatment Trialists' Collaboration, Ninomiya T, Perkovic V, Turnbull F, Neal B, Barzi F, Cass A, Baigent C, Chalmers J, Li N, Woodward M, MacMahon S: Blood pressure lowering and major cardiovascular events in people with and without chronic kidney disease: meta-analysis of randomized controlled trials. BMJ 2013, 347:55680.

80. Fried LF, Emanuele N, Zhang JH, Brophy M, Conner TA, Duckworth W, Leehey DJ, McCullough PA, O'Connor T, Palevsky PM, Reilly RF, Seliger SL, Warren SR, Watnick S, Peduzzi P, Guarino P, for the VA NEPHRON-D Investigators: Combined angiotensin inhibition for the treatment of diabetic nephropathy. N Engl J Med 2013, 369:1892-1903.

81. Berl T, Hunsicker LG, Lewis JB, Pfeffer MA, Porush JL, Rouleau JL, Drury PL, Esmatjes E, Hricik D, Parikh CR, Raz I, Vanhille P, Wiegmann TB, Wolfe BM, Locatelli F, Goldhaber SZ, Lewis EJ, Irbesartan Diabetic Nephropathy Trial. Collaborative Study Group: Cardiovascular outcomes in the Irbesartan Diabetic Nephropathy Trial of patients with type 2 diabetes and overt nephropathy. Ann Inter Med 2003, 138:542-549.

82. Imai E, Chan JC, Ito S, Yamasaki T, Kobayashi F, Haneda M, Makino H, for the the ORIENT study investigators: Effects of olmesartan on renal and cardiovascular outcomes in type 2 diabetes with over nephropathy: a multicentre, randomised, placebo-controlled study. Diabetologia 2011, 54:2978-2986.

83. Mann JF, Schmieder RE, McQueen M, Dyal L, Schumacher H, Pogue J, Wang X, Maggioni A, Budaj A, Chaithiraphan S, Dickstein K, Keltai M, Metsarinne K, Oto A, Parkhomenko A, Piegas LS, Syendsen TL, Teo KK, Yusuf S, on behalf of the ONTARGET investigators: Renal outcomes with telmisartán, ramipril, or both, in people at high risk (the ONTARGET study): a multicentre, randomised, double-blind, controlled trial. Lancet 2008, 372:547-553.

84. Lopez-Jaramillo P: Defining the research priorities to fight the burden of cardiovascular diseases in Latin America. J Hypertens 2008, 26:1886-1889.

doi:10.1186/1758-5996-6-31

Cite this article as: Lopez-Jaramillo et al:: The goal of blood pressure in the hypertensive patient with diabetes is defined: now the challenge is go from recommendations to practice. Diabetology \& Metabolic Syndrome $20146: 31$.

\section{Submit your next manuscript to BioMed Central and take full advantage of:}

- Convenient online submission

- Thorough peer review

- No space constraints or color figure charges

- Immediate publication on acceptance

- Inclusion in PubMed, CAS, Scopus and Google Scholar

- Research which is freely available for redistribution 